\title{
Corneal Biomechanics in Patients with Glaucoma: The Effect of Pupillary Dilatation
}

\author{
Glokom Hastalarında Korneal Biyomekanikler: Pupilla \\ Dilatasyonunun Etkisi
}

Refik Oltulu ${ }^{1}$

Selman Belviranli ${ }^{1}$,

Gunhal Satirtav ${ }^{1}$,

Orhan Altunkaya ${ }^{2}$,

Emine Tinkir Kayitmazbatir ${ }^{3}$,

Mehmet Okka ${ }^{1}$,

'Necmettin Erbakan University Meram Faculty of Medicine, Department of Ophthalmology, Konya, Turkey

${ }^{2}$ Sabuncuoglu Serefeddin Education and Research Hospital Department of Ophthalmology, Amasya, Turkey

${ }^{3}$ Sorgun State Hospital, Department of

Ophthalmology, Yozgat, Turkey

Geliş Tarihi/Received: 25 May 2018

Kabul Tarihi/Accepted: 26 August 2018

Address correspondence to: Refik Oltulu, Necmettin Erbakan University Meram Faculty of Medicine, Department of Ophthalmology, Meram, Konya, Turkey

e-mail: refikoltulu@gmail.com

\section{ORCID}

Refik Oltulu

https://orcid.org/0000-0003-2447-6524
Öz

Amaç: Primer açık açılı glokomlu (PAAG) gözlerde oküler cevap analizörü kullanılarak pupilla dilatasyonunun göziçi basıncı ve kornea biyomekaniklerine etkisinin değerlendirilmesi

Hastalar ve Yöntem: PAAG'li 15 olgunun 28 gözünde tek damla \%0.5 tropikamid uygulaması öncesi ve 30 dakika sonrasında Goldmann ile uyumlu göz içi basıncı ( $\mathrm{GiBg}$ ), korneanın biyomekanik özellikleri ile kompanse edilmiş GiB (GlBkk), kornea rezistans faktörü (KRF) ve kornea histerezisi (KH) değerlendirildi. Bulgular: Olguların ortalama yaşı 57.7 \pm 13.2 (45-65 yıl) idi. Tropikamid uygulaması öncesi ortalama $\mathrm{KH}$ $9.5 \pm 2.2 \mathrm{mmHg}$, KRF $10.1 \pm 2.1 \mathrm{mmHg}$, GiBg $16.9 \pm 3.5 \mathrm{mmHg}$ ve GiBkk $18.2 \pm 4.0 \mathrm{mmHg}$ iken uygulama sonrası bu değerler sırasıyla $9.7 \pm 2.2 \mathrm{mmHg}, 10.1 \pm 2.0 \mathrm{mmHg}, 16.2 \pm 2.8 \mathrm{mmHg}$ ve17.2 $\pm 3.6 \mathrm{mmHg}$ olarak tespit edildi. Tropikamid uygulaması öncesi ve sonrası GiBg ve GiBkk değerlerindeki fark istatistiksel olarak anlamlı iken $(p=0.043, p=0.015$, sırasıyla), KH ve KRF için istatistiksel olarak anlamlı fark tespit edilmedi ( $p=0.057 p=0.702$, sırasıyla).

Sonuç: PAAG olgularında \% 0.5 tropikamid ile oluşturulan pupilla dilatasyonunun korneal biyomekanikler üzerine herhangi bir etkisi gözlenmezken GỉB üzerine azaltıcı bir etkisi var gibi görünmektedir.

Anahtar Kelimeler: Korneal biyomekanikler, Glokom, Oküler cevap analizörü, Tropikamid, Pupilla dilatasyonu

\section{Abstract}

Aim: The objective of this study was to assess the effect of pupillary dilatation on intraocular pressure and corneal biomechanical properties using ocular response analyzer in patient with primary open angle glaucoma.

Patients and Methods: Goldmann correlated intraocular pressure, corneal corrected intraocular pressure, corneal hysteresis and corneal resistance factor were all respectively evaluated in 28 eyes of 15 patients with primary open angle glaucoma before and 30 minutes after tropicamide $0.5 \%$ instillation.

Results: The mean age was found as $57.7 \pm 13.2$ (range 45-65) years. The mean corneal hysteresis, corneal resistance factor, Goldmann correlated intraocular pressure and corneal corrected intraocular pressure measurements were $9.5 \pm 2.2 \mathrm{mmHg}, 10.1 \pm 2.1 \mathrm{mmHg}, 16.9 \pm 3.5 \mathrm{mmHg}, 18.2 \pm 4.0 \mathrm{mmHg}$ before instillation of tropicamide, and $9.7 \pm 2.2 \mathrm{mmHg}, 10.1 \pm 2.0 \mathrm{mmHg}, 16.2 \pm 2.8 \mathrm{mmHg}, 17.2 \pm 3.6 \mathrm{~mm} \mathrm{Hg} 30$ minutes after instillation of tropicamide, respectively. Statistically significant differences were found between Goldmann correlated intraocular pressures and corneal corrected intraocular pressures measured before and afte tropicamide instillation ( $p=0.043, p=0.015$, respectively), while no statistically significant differences were found between before and after measurements in terms of corneal hysteresis and corneal resistance factor $(p=0.057 p=0.702$, respectively).

Conclusions: Pupillary dilatation with tropicamide $0.5 \%$ seems to have a decreasing effect on intraocular pressure while no effect was noted for corneal biomechanical properties of primary open angle glaucoma patients

Key words: Corneal biomechanics, Glaucoma, Ocular response analyzer, Tropicamide, Pupillary dilation

\section{INTRODUCTION}

In vivo measurement of the corneal resistance against deformation has been introduced by the development of ocular response analyzer (ORA; Reichert Ophthalmic Instruments, Depew, NY) by Luce (1). ORA measures two major corneal biomechanical parameters including corneal resistance factor (CRF) and corneal hysteresis $(\mathrm{CH})$. While CRF is an empirically defined parameter which is thought to reflect the overall corneal resistance, $\mathrm{CH}$ predominantly reflects corneal viscous properties (2). Besides biomechanical parameters of the cornea, the ORA also measures a Goldmann-correlated IOP (IOPg) and a corneal-compensated intraocular pressure (IOPcc). The IOPcc considers the corneal hysteresis as independent of the viscoelastic parameters of the cornea. The IOPg is the arithmetic mean of both applanation pressures.

IOP measurement may be affected by the corneal rigidity, which can be different in persons
Cite this article as: Oltulu R, Belviranli S, Satirtav G, Altunkaya O, Kayitmazbatir ET, Okka M. Corneal Biomechanics in Patients with Glaucoma: The Effect of Pupillary Dilatation. Selcuk Med J 2019;35(1): 15-18
Disclosure: None of the authors has a financial interest in any of the products, devices, or drugs mentioned in this article. The research was not sponsored by an outside organization. All authors have agreed to allow full access to the primary data and to allow the journal to review the data if requested. 
because of the corneal tissue structure. It has also been shown that the rate of glaucoma progression is faster in eyes with lower corneal hysteresis. It has been proposed that the corneal biomechanical properties might influence the risk for development of glaucomatous optic neuropathy (3). Multiple factors may affect corneal biomechanical properties which consequently influence IOP measurements. Previously we have shown that pupillary dilatation may alter corneal biomechanical properties and IOP in healthy individuals $(4,5)$.

Tropicamide is an acetylcholine receptor blocker agent with short acting cycloplegic and mydriatic effects. It is commonly used to achieve mydriasis for fundus examination in ophthalmology. It is available in forms of $1 \%$ and $0.5 \%$ ophthalmic solutions. Its maximum effect is revealed in about 20 to $25 \mathrm{~min}$ and complete recovery occurs within 4 to 6 hours. (6).

The objective of this study was to assess the effect of pupillary dilatation on intraocular pressure and corneal biomechanical properties using ORA in patient with primary open angle glaucoma (POAG). To the best of our knowledge, the alterations in corneal biomechanical properties in POAG patients after pupillary dilatation have not been reported previously.

\section{PATIENTS AND METHODS}

Fifteen patients from the Glaucoma Division of the Department of Ophthalmology, Necmettin Erbakan University Meram Faculty of Medicine were enrolled in this observational, cross-sectional study. Eyes with documented POAG that reached the established target IOP under medical treatment were included. The study was approved by the local Ethics Committee and conducted in line with the principles of the Declarations of Helsinki. All participants gave informed consent before beginning of the study.

Subjects were excluded if they had myopic and hyperopic refractive errors of greater than -2.0 or +2.0 diopters or a history of intraocular or refractive surgery, active ocular infection, diabetes, contact lens use, or any corneal pathology, including Fuchs' corneal dystrophy and keratoconus. Patients underwent a complete ophthalmological examination, including ORA measurements. Diagnosis of POAG is based on optic nerve morphology characteristics of glaucomatous optic neuropathy, and corresponding reproducible glaucomatous visual-field defects on standard automated perimetry (SAP: achromatic 24-2 Sita-Standard strategy, Humphrey visual Field Analyzer 750i, Humphrey Instruments, Dublin, CA).
All patients were assessed with the ORA before and 30 min after instillation of one drop of tropiconid $0.5 \%$. The $\mathrm{CH}, \mathrm{CRF}$, mean IOPcc, and IOPg values were measured with a patented dynamic bidirectional applanation process. All ORA measurements were read by the same experienced technician in the patient sitting comfortably in a chair which was found in a separate room. Four high quality well-defined symmetric inward, and outward applanation spikehigh measurements were recorded for each eye, and the mean values were used for the analysis.

All statistical analyses were performed using SPSS v. 15.0 (SPSS for Windows, ver. 15.0; SPSS Inc., Chicago, IL) software. The values are presented as mean \pm standard deviation (SD). The variables before and after tropicamide administration were compared using Paired samples t-test . $p$ values $<0.05$ were considered statistically significant.

\section{RESULTS}

Twenty-eight eyes of 15 subjects [8 male $(53.33 \%), 7$ female $(46.67 \%)]$ were analysed. The mean age was $57.7 \pm 13.2$ years (range $45-$ 65 years). The mean $\mathrm{CH}, \mathrm{CRF}, \mathrm{IOPg}$ and IOPcC measurements of the eyes were $9.5 \pm 2.2 \mathrm{mmHg}$, $10.1 \pm 2.1 \mathrm{mmHg}, 16.9 \pm 3.5 \mathrm{mmHg}, 18.2 \pm 4.0 \mathrm{mmHg}$ before tropicamide instillation, and $9.7 \pm 2.2 \mathrm{mmHg}$, $10.1 \pm 2.0 \mathrm{mmHg}, 16.2 \pm 2.8 \mathrm{mmHg}, 17.2 \pm 3.6 \mathrm{mmHg}$ after tropicamide instillation, respectively. There were statistically significant differences between pre- and post-tropicamide instillation measurements of IOPg and IOPcc ( $p=0.043, p=0.015$, respectively) while no statistically significant differences were found for the $\mathrm{CH}$ and CRF. ( $p=0.057 p=0.702$, respectively). The results are summarized in Table 1.

\section{DISCUSSION}

Corneal biomechanical properties are important in many ocular disorders and their evaluation can provide knowledge to pathologic changes of the cornea. It has been shown that $\mathrm{CH}$ is affected with some ocular diseases such as glaucoma, keratoconus, Fuchs' dystrophy, and post-LASIK patients (7-10). However, the influence of pupillary dilatation on corneal biomechanical properties in glaucomatous eyes is not well documented..

In the present study, we have shown a decrease in IOP values in contrast to the results of the studies by Kim JM et al (11) and Mocan MC (12) et al. that reported an increase in IOP after pupillary dilatation with tropicamide eye drops. In their study, Shaw 
Table 1. The measured values of $\mathrm{CH}, \mathrm{IOPcC}, \mathrm{CRF}$ and IOPg in the pre and post-tropicamide.

\begin{tabular}{lccc}
\hline & Pre-tropicamide & Post-tropicamide & p Value $^{*}$ \\
\hline $\mathrm{CH}(\mathrm{mmHg})$ & $9.5 \pm 2.2$ & $9.7 \pm 2.2$ & 0.057 \\
$\mathrm{CRF}(\mathrm{mmHg})$ & $10.1 \pm 2.1$ & $10.1 \pm 2.0$ & 0.702 \\
$\mathrm{IOPg}(\mathrm{mmHg})$ & $16.9 \pm 3.5$ & $16.2 \pm 2.8$ & 0.043 \\
IOPcC $(\mathrm{mmHg})$ & $18.2 \pm 4.0$ & $17.2 \pm 3.6$ & 0.015 \\
\hline
\end{tabular}

$\overline{\mathrm{CH}}$, corneal hysteresis; $\mathrm{CRF}$, corneal resistance factor; IOPcc, corneal compensated intraocular pressure; IOPg, Goldmann applanation compensated intraocular pressure.

${ }^{*}$ Paired t-test.

and Lewis (13) found significant pressure elevations in $32 \%$ of patients with open angle glaucoma after pupillary dilatation with $2.5 \%$ phenylephrine and $1 \%$ tropicamide. Siam et al. (14) reported the change in IOP after dilatation as between $-8 \mathrm{mmHg}$ and $+10 \mathrm{mmHg}$. The mechanism responsible for IOP fluctuation following pupillary dilatation is not fully known. The most important and commonly accepted mechanism that induce elevated IOP in glaucomatous eyes is the liberation of iris pigment into the anterior chamber and followed by obstruction of the trabecular meshwork. Another mechanism that has been described is decreased contractility of ciliary muscle on the trabecular meshwork, resulting in a decrease in aqueous outflow (12). However, these suggested hypotheses do not seem to fully explain the mechanism of increase in IOP after pupillary dilatation.

In our study, the mean IOP values were increased in 9 patients $(32.1 \%)$ after pupillary dilatation. This can be explained by the mechanisms described above. However, in the majority of our patients we detected a decrease in the IOP value. Furthermore, results of present study are concordant with our previous findings (5). Transient impair of aqueous flow balance may affects these patients. In addition, pupillary dilation can lead to a wider contact region between the humor aqueous and trabecular meshwork, and a greater anterior chamber depth. Therefore, IOP may not increase following pupillary dilation. It may be advised that, during the evaluation of IOP of patients with POAG, the ORA measurements be taken before tropicamide instillation.

Some previous studies have demonstrated that $\mathrm{CH}$ was significantly lower in glaucomatous patients compared to healthy controls $(15,16)$. Another study has also concluded that reduced $\mathrm{CH}$ could be an important marker of increased vulnerability of the optic nerve against glaucomatous damage (17). Therefore, low $\mathrm{CH}$ levels likely increase the risk for developing glaucomatous optic neuropathy.
While the $\mathrm{CH}$ values are important in evaluating glaucoma patients, the possible effect of pupillary dilatation on values of $\mathrm{CH}$ would be important for us. However our results revealed that the corneal biomechanical properties are not significantly altered by the administration of tropicamide.

Our study was conducted with instillation of one drop tropicamide and measuring its effect on ORA measurements. In most cases, 2-3 drops of tropicamide are used 10-15 minutes apart for pupillary dilation. Therefore, more frequent instillation of tropicamide may give rise to different results and thus, should be further studied.

There were some limitations in this study. First, our results may be limited by the relatively small sample size. Therefore, further well-designed studies with larger sample sizes are warranted to confirm our findings. Second, the possible effects of glaucoma medications on corneal hysteresis in glaucoma patients.

In conclusion, our results suggest that patients with POAG may have decreased IOP after pupillary dilatation. The effects of pupillary dilatation on IOP measurements should be considered during examination of POAG patients.

Conflict of interest: Authors declare that there is no conflict of interest between the authors of the article.

Financial conflict of interest: Authors declare that they did not receive any financial support in this study.

Address correspondence to: Refik Oltulu, MD Necmettin Erbakan University Meram Faculty of Medicine, Department of Ophthalmology. Meram, Konya, Turkey 42080 Phone: +90 5057538080 Fax: +903322236182 e-mail: refikoltulu@gmail.com

\section{REFERENCES}

1. Luce DA. Determining in vivo biomechanical properties of thecornea with an ocular response analyzer. J Cataract Refract Surg 2005;31:156-62.

2. Kotecha A. What biomechanical properties of the cornea are relevant for the clinician? Surv Ophthalmol 2007;52:109-14. 
3. Medeiros FA, Meira-Freitas D, Lisboa R, et al. Corneal hysteresis as a risk factor for glaucoma progression: A prospective longitudinal study. Ophthalmology 2013;120(8):1533-40.

4. Oltulu R, Satirtav G, Kerimoğlu H, et al. Influence of cyclopentolate hydrochloride on corneal biomechanical properties in healthy individuals. Eye Contact Lens 2014;40(5):309-11.

5. Oltulu R, Satirtav G, Altunkaya O, et al. Effect of mydriasis induced by topical $0.5 \%$ tropicamide instillation on the corneal biomechanical properties in healthy individuals measured by ocular response analyzer. Cutan Ocul Toxicol 2015;34(1):357.

6. Hardman JG, Gilman AG, Limbird LE. The Pharmacological Basis of Therapeutics. 10th ed. New York: McGraw-Hill; 2001;1673-85.

7. Shah S, Laiquzzaman M, Yeung I, et al. The use of the Ocular Response Analyser to determine corneal hysteresis in eyes before and after excimer laser refractive surgery. Cont Lens Anterior Eye 2009;32(3):123-8.

8. del Buey MA, Cristóbal JA, Ascaso FJ, et al. Biomechanical properties of the cornea in Fuchs' corneal dystrophy. Invest Ophthalmol Vis Sci 2009;50(7):3199-202.

9. Wolffsohn JS, Safeen S, Shah S, et al. Changes of corneal biomechanics with keratoconus. Cornea 2012;31(8):849-54.

10. Costin BR, Fleming GP, Weber PA, et al. Corneal biomechanical properties affect Goldmann applanation tonometry in primary open-angle glaucoma. J Glaucoma 2014;23(2):69-74
11 Kim JM, Park KH, Han SY, et al. Changes in intraocular pressure after pharmacologic pupil dilation. BMC Ophthalmol 2012;12:53.

12. Mocan MC, Ustunel S, Dikmetas $\mathrm{O}$, et al. The effect of pharmacologic pupillary dilatation on anterior segment parameters in patients with exfoliation syndrome. J Optom 2014;7(1):51-6.

13. Shaw BR, Lewis RA: Intraocular pressure elevation after pupillary dilation in open angle glaucoma. Arch Ophthalmol 1986;104(8):1185-8.

14 Siam GA, de Barros DS, Gheith ME, et al. The amount of intraocular pressure rise during pharmacological pupillary dilatation is an indicator of the likelihood of future progression of glaucoma. Br J Ophthalmol 2007;91(9):1170-2.

15. Abitbol O, Bouden J, Doan S, et al. Corneal hysteresis measured with the Ocular Response Analyzer in normal and glaucomatous eyes. Acta Ophthalmol 2010;88:116-9.

16. Mangouritsas G, Morphis G, Mourtzoukos S, et al. Association between corneal hysteresis and central corneal thickness in glaucomatous and non-glaucomatous eyes. Acta Ophthalmol 2009;87:901-5.

17 Bochmann F, Ang GS, Azuara-Blanco A. Lower corneal hysteresis in glaucoma patients with acquired pit of the optic nerve (APON). Graefes Arch Clin Exp Ophthalmol 2008;246:735-8 